\title{
The use of botulinum toxin for the treatment of patients with overactive bladder
}

\section{Zastosowanie toksyny botulinowej w leczeniu pacjentek z pęcherzem nadreaktywnym}

\author{
Agnieszka Licow ${ }^{1 凶}$, Sylwester Ciećwież' ${ }^{1}$ Magdalena Ptak², Dariusz Kotlęga ${ }^{3,4}$, Andrzej Starczewski1, \\ Agnieszka Brodowska ${ }^{1}$
}

${ }^{1}$ Pomorski Uniwersytet Medyczny w Szczecinie, Klinika Ginekologii, Endokrynologii i Onkologii Ginekologicznej, ul. Unii Lubelskiej 1, 71-252 Szczecin

Pomeranian Medical University in Szczecin, Department of Gynecology, Endocrinology and Gynecologic Oncology

${ }^{2}$ Pomorski Uniwersytet Medyczny w Szczecinie, Zakład Rehabilitacji Medycznej i Fizjoterapii Klinicznej, ul. Żołnierska 54, 71-210 Szczecin

Pomeranian Medical University, Medical Rehabilitation and Clinical Physiotherapy Department

${ }^{3}$ Pomorski Uniwersytet Medyczny w Szczeicnie, Oddział Neurologii, ul. Unii Lubelskiej 1, 71-252 Szczecin

Pomeranian Medical University in Szczecin, Department of Neurology

${ }^{4}$ Głogowski Szpital Powiatowy, Oddział Neurologii, ul. Kościuszki 15, 67-200 Głogów

District Hospital in Głogów, Department of Neurology

$\triangle$ alicow@interia.pl

\begin{abstract}
Overactive bladder affects $12-17 \%$ of the population, and mainly women, and its incidence increases with age. Diagnosis of this condition is based mainly on the patients' complaints. These symptoms significantly affect the quality of life of millions of patients, involving considerable social, psychological, professional, physical and sexual problems. The wide incidence of this condition makes it necessary to find new medical substances in order to effectively eliminate the symptoms. Neurotoxins are a group of medical drugs that hold great promise for the future. Botulinum toxin is currently being used to treat symptoms
\end{abstract}

related to overactive bladder. It can constitute an appropriate therapeutic option, in particular with regard to patients for whom the use of standard anti-cholinergic drugs is unsatisfactory or leads to severe side effects. Numerous research studies confirm that botulinum toxin can be efficiently used in the treatment of overactive bladder. The properties of this neurotoxin allow selective deactivation of overactive muscles. The use of botulinum toxin can be a method of treatment that significantly improves patient quality of life.

Keywords: botulinum toxin; overactive bladder; urinary incontinence; quality of life.

\section{ABSTRAKT}

Pęcherz nadreaktywny dotyczy $12-17 \%$ populacji, głównie kobiet, a częstość zachorowań wzrasta z wiekiem. Rozpoznanie tego schorzenia opiera się głównie na występowaniu objawów zgłaszanych przez pacjentów. W znaczący sposób wpływają one na jakość życia milionów chorych. Są związane z występowaniem znacznych problemów społecznych, psychologicznych, zawodowych, fizycznych i seksualnych. Tak szerokie rozpowszechnienie tego schorzenia powoduje konieczność poszukiwania nowych substancji leczniczych w celu skutecznego zwalczania objawów choroby. Grupą leków, z którą wiąże się obecnie duże nadzieje na przyszłość, są neurotoksyny. W ostatnim czasie w leczeniu objawów związanych z nadreaktywnością pęcherza moczowego wykorzystuje się toksynę botulinową. Toksyna botulinowa może stanowić właściwą opcję terapeutyczną, szczególnie w odniesieniu do pacjentów, w przypadku których standardowo stosowane leki antycholinergiczne cechują się niewystarczającą efektywnością lub nasilonym objawami niepożądanymi. Liczne badania potwierdzają, że toksynę botulinową można efektywnie stosować w leczeniu pęcherza nadreaktywnego. Właściwości tej neurotoksyny stwarzają możliwość selektywnego wyłączania nadreaktywnych mięśni. Zastosowanie toksyny botulinowej może być metodą leczniczą znacząco wpływającą na poprawę jakości życia pacjentów.

Słowa kluczowe: toksyna botulinowa; pęcherz nadreaktywny; nietrzymanie moczu; jakość życia.

\section{INTRODUCTION}

Overactive bladder syndrome (OAB), according to the definition from the International Continence Society (ICS), is a multisymptom condition characterized by urinary urgency, with or without urinary incontinence, i.e. involuntary loss of urine following an urgent need to urinate [1]. Overactive bladder is diagnosed on the basis of such symptoms as a sudden urge to urinate, usually with higher frequency of daytime micturition and nocturia [2], in the absence of such pathologies as urinary tract infections, interstitial nephritis, bladder tumor, bladder calculi, or neurological diseases [3]. The definition formulated in such a manner allows for the diagnosis of this condition without an obligatory performance of urodynamic examination [4].

Diagnosis of OAB is based mainly on the patients' complaints [5]. These symptoms significantly affect quality of life of millions of patients. They are associated with considerable social, psychological, professional, physical and sexual problems. They can also contribute to developing depression. 


\section{Prevalence of overactive bladder syndrome}

Overactive bladder syndrome affects $12-17 \%$ of the population, mainly women, and the incidence increases with age [6]. It is estimated that nearly $70 \%$ of women over 50 suffer from urinary incontinence. In almost $1 / 3$ of the women it is one of the symptoms of OAB [7]. The results of the National Overactive Bladder Evaluation (NOBLE) studies, involving 2700 women in the USA and published in 2003, showed a clear relationship between the prevalence of $\mathrm{OAB}$ and the ageing process [8].

In accordance with epidemiological studies carried out in 6 European countries (France, Germany, Italy, Spain, Sweden and the UK) involving 16,776 men and women, the average prevalence of $\mathrm{OAB}$ was as high as $16.6 \%$. The incidence of symptoms increased with age - from $8.7 \%$ in women aged 40-44 to $31.3 \%$ in women over 75 . On the basis of the extrapolation, it was calculated that in 6 European countries there are about 18 million people suffering from $\mathrm{OAB}$ [9].

\section{The quality of life of patients with overactive bladder}

Overactive bladder is a common condition whose symptoms may considerably reduce the quality of life. In a study carried out by Sako et al., the authors assessed the impact of overactive bladder symptoms on sexual function in Japanese women [10]. The results demonstrated that $\mathrm{OAB}$ symptoms significantly contributed to sexual dysfunction in these Japanese women. Another study (Seul, 2017) showed that in about $1 / 3$ of OAB cases the greatest discomfort is related to urine leakage. Considerably reduced quality of life as well as an increased rate of depression and stress are found in patients with OAB compared with the patients who can hold their urine. In particular, it pertains to those patients who do not respond to pharmacological treatment [11]. Overactive bladder is a condition frequently affecting also children and is more likely to occur in girls. Similarly as in adults, it constitutes a major individual, family and social problem [12].

\section{Overactive bladder syndrome treatment}

The high prevalence of $\mathrm{OAB}$ syndrome leads to the necessity of seeking new medical substances in order to effectively treat the condition, to minimize the impact on patients' quality of life. Since 1970, the treatment of OAB symptoms has become more effective. At that time, initiation of the treatment with the use of oxybutynin, the 1st non-selective anticholinergic drug, was followed by the introduction of other products acting on muscarinic receptors of the urinary bladder [13]. The effectiveness of oxybutynin amounts to about $24 \%$, however, the severity of side effects, i.e. dry mouth, constipation and other gastrointestinal symptoms, is the reason for which a significant percentage of patients gave up the therapy (up to about $80 \%$ during a year) [14].

One group of highly promising drugs are neurotoxins. Recently, botulinum toxin has been used in the treatment of symptoms related to $\mathrm{OAB}$.

\section{Botulinum toxin - effects and application in medicine}

In the years 1817-1822, Justinus Kerner documented the symptoms associated with botulism. On 14th December 1987, 34 Belgian musicians suffered food poisoning from smoked ham, and 1 of them died. Leftovers of the ham and some organs from the deceased were sent to Emile van Ermengem, Professor of bacteriology at the University of Ghent. He found the toxin responsible for the poisoning and named it Bacillus botulinum. At the beginning of the 2oth century, the word Clostridium (the shape of a spindle) replaced the word Bacillus (Clostridium botulinum). Later, during World War II, Carl Lamanna and Edward Schantz managed to isolate and purify the toxin in the U.S. Army laboratories. Schantz continued research on the toxin at the University of Wisconsin with Eric Johnson and other co-workers. In 1965, Drachman demonstrated paralysis and atrophy in chicken muscles following botulinum toxin injection. These findings encouraged Allan Scott, an ophthalmologist, to conduct further investigations. His pioneering research related to the treatment of strabismus with botulinum toxin led to the approval of the toxin to be used in various fields of medicine [15] - Table 1 .

Botulinum toxin was soon recognized as one of the strongest biological toxins $[16,17]$. It is produced by Clostridium botulinum bacteria. Depending on the strain of bacteria, 7 types of botulinum toxins can be distinguished, denoted by the subsequent letters A-G [18]. All types of botulinum toxin have a similar mechanism of action, but they differ in terms of their degree of toxicity. Two serotypes: A and B are mainly used in medicine.

Botulinum toxin A is 1 of 7 neurotoxins produced by the anaerobic bacteria Clostridium botulinum and is the most potent biological toxins known [19]. It causes muscle paralysis by blocking the release of acetylcholine from cholinergic nerves [20]. Botulinum neurotoxins (BoNT) are di-chain proteins comprised of an $\mathrm{N}$-terminal zinc metalloprotease light chain (LC) and a C-terminal heavy chain (HC), which includes the translocation and receptor binding domains. The 2 chains are held together by a disulfide bond. The LC cleaves soluble $\mathrm{N}$-ethylmaleimide-sensitive factor attachment protein receptors (SNAREs). The cleavage of SNAREs inhibits the fusion of synaptic vesicles to the cell membrane and the subsequent release of acetylcholine, which results in flaccid paralysis. The LC controls the catalytic properties and the duration of BoNT action [21] - Figure 1.

In most cases, the application of botulinum toxin does not result in muscle paralysis, but in a decrease of excessive tension.

Botulinum toxin has relatively few side effects. On account of the local application of the drug, its systemic action is rare and is related to the diffusion of the drug from the place of application to the adjacent or distant muscles [22].

Botulinum toxin A was first injected in 1988 in rhabdosphincter in patients with spinal cord injury resulting in detrusorsphincter dyssynergia [23]. It resulted in a neuromuscular block in the area of rhabdosphincter and significantly decreased 
TABLE 1. The use of botulinum toxin A in medicine [16]

Field of medicine
Medical condition

different types of strabismus: strabismus concommitans, strabismus convergens esotropia, strabismus divergens exotropia, strabismus latens heterophoria, congenital, paraliticus, postoperative residual strabismus, convergence insufficiency; nystagmus and other acquired ocular motor disorders; excessive tearing; defective eyelid closure; intended temporary drooping of the upper eyelid; eyelid retraction; myokymia; spastic entropion

dystonias:
- focal: Meige's syndrome, oromandibular dystonia, tongue dystonia, bruxizm, spastic blepharospasm, cervical dystonia,
throat dystonia, laryngeal dystonia,
- segmental dystonias,
- hemidystonia,
- generalized dystonia,
- symptomatic dystonias: Hallervorden-Spatz disease
spasticity:
- focal limb spasticity,
- non-focal: hemispasticity, paraspsaasticity, tetraspasticity

hemifacial spasm; synkineses after abnormal reinnervation; ticks; cerebral palsies; facial nerve paralysis and crocodile
tears syndrome; synkinesis after idiopathic facial nerve paralysis
hyperhidrosis:
- focal: axillary, palmar, plantar,
- generalized
salivation: Parkinsonism, amyotrophic lateral sclerosis, muscle tremors

pain:
- muscle pain: caused by dystonias, spasticity, fibromyalgia, chronic facial muscle pain, chronic paraspinal muscles pain,
- non-muscle pain: migraine, neuropathic pain, trigeminal neuralgia, phantom pain
other:

Urology

dissynergy of detrusor and sphincter muscles; idiopathic detrusor overactivity; neurogenic detrusor overactivity; urinary retention; bladder pain syndrome; pelvic floor muscles spasm; benign prostatic hyperplasia

Otolaryngology gustatory sweating (Frey's syndrome); chronic rhinitis; laryngeal granulomas; glottic obstruction

\begin{tabular}{ll} 
Paediatrics & cerebral palsy \\
\hline Gastroenterology & $\begin{array}{l}\text { achalasia; cricopharyngeal spasm (inferior pharyngeal contrictor muscle); esophageal achalasia; pyloric stenosis; } \\
\text { hirschprung's disease; sphincter of oddi spasm; gastroparesis; other: anal fissures, proctalgia fugax, anismus, obesity }\end{array}$ \\
\hline Orthopaedics & dynamic clubfoot
\end{tabular}

Aesthetic medicine glabellar wrinkles; wrinkles of inner eye corners

postvoid residual urine volume by allowing the urinary bladder to empty. Botulinum toxin can be a suitable therapeutic option, particularly for patients for whom conventional anticholinergic medication is insufficiently effective or leads to more serious side effects. Injections of botulinum solution into the bladder are performed during cystoscopy without the need for general anaesthesia. The fact that the therapeutic effect after a single injection may last even up to 9-12 months, and in some cases longer, constitutes a significant clinical advantage of botulinum toxin A. As a result, patients do not need to remember to take their medicines everyday [24].

\section{Botulinum toxin as a method of overactive bladder syndrome treatment}

Placebo-controlled trials confirm the long-term effects of botulinum toxin $\mathrm{A}$. As a result, it started to be used in $\mathrm{OAB}$ treatment [25]. A study published in 2017 by the British Journal of Urology showed that 162 out of 195 patients with neurogenic detrusor overactivity experienced $a \geq 50 \%$ reduction in urinary incontinence following the botulinum toxin A treatment [26]. Injections into the bladder walls are highly efficacious in patients with $\mathrm{OAB}$ resistant to pharmacological treatment [27]. Patients need to receive repeated botulinum 


\section{Intramuscular injection of botulinum toxin type A}

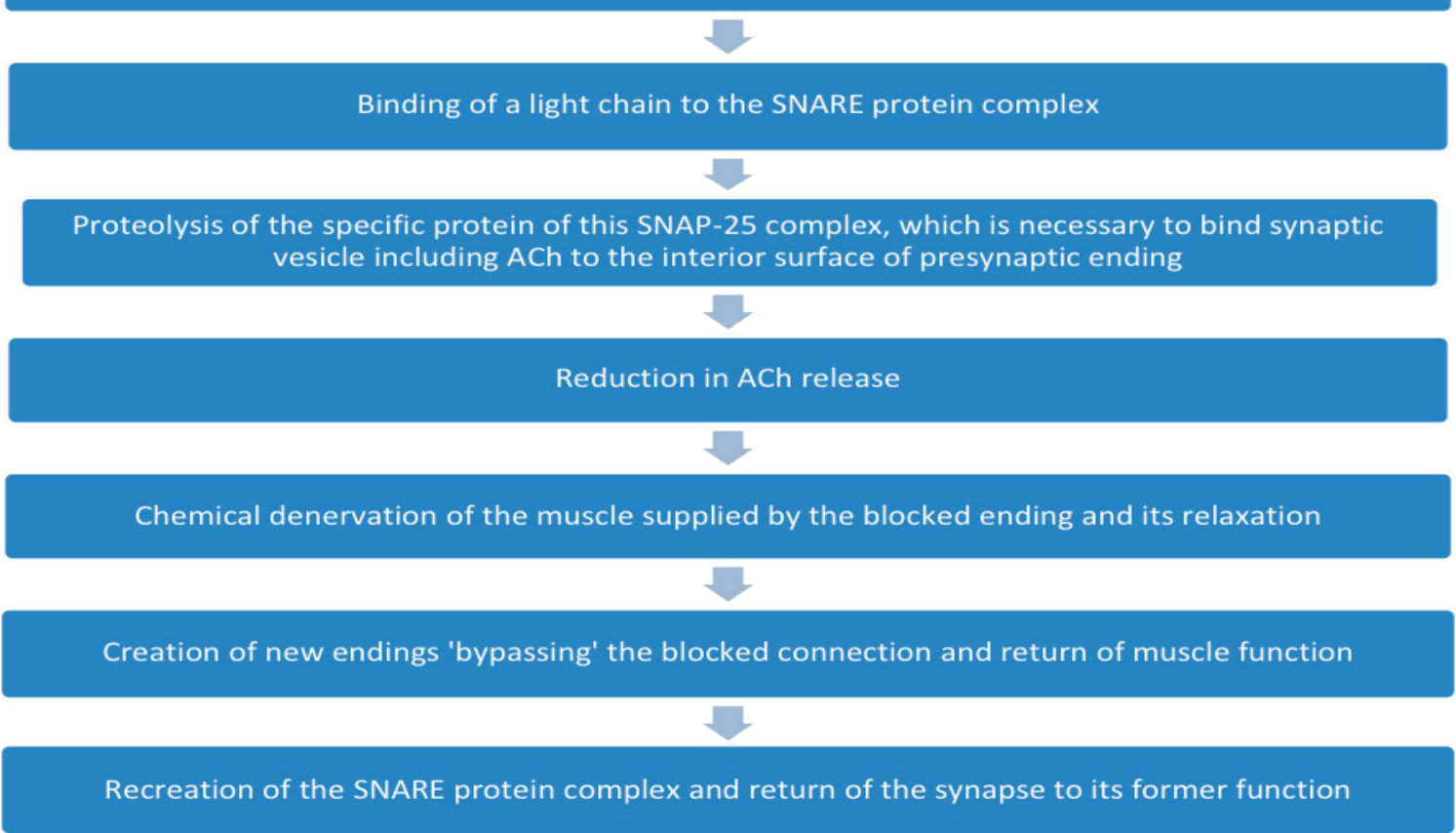

ACh - acetylcholine

FIGURE 1. The sequence of events following the injection of botulinum toxin for muscle relaxation [22]

toxin injections after 5-9 months (but not earlier than after 3 months following its application) [28]. British Journal of Urology reports that the use of botulinum toxin A provides greater relief of OAB symptoms compared with most other drugs used in OAB treatment [29]. The Canadian Journal of Urology published the study demonstrating that botulinum toxin A is effective and efficient in $\mathrm{OAB}$ treatment [30].

In 2018, Einstein published the results of randomized studies carried out in Brazil, which indicate significantly better results of the botulinum toxin A injection than oral administration of oxybutynin in patients with neurogenic detrusor overactivity [31]. The Brazilian Journal of Infectious Diseases reported that an intravesical administration of botulinum toxin $\mathrm{A}$ reduced $\mathrm{OAB}$ with a long-term effect and improved the quality of life of HTLV-1 infected patients with severe overactive bladder [32]. The study conducted in Germany and published by Frontiers in Surgery showed that botulinum toxin therapy is an efficient, safe and life-improving treatment for patients with idiopathic overactive bladder [33]. Despite the fact that botulinum toxin has been successfully used for almost 40 years in various fields of medicine - ophthalmology, neurology, orthopaedics, laryngology and dentistry, it is still primarily associated with aesthetic medicine and so called beauty treatments [33].

\section{CONCLUSION}

Botulinum toxin can be successfully used in OAB treatment, which significantly improves the quality of life of patients suffering from the condition. Its properties allow selective deactivation of overactive muscles which cannot be achieved using other methods. However, further research is needed to identify all aspects of its action and the safe use of botulinum toxin in OAB treatment.

\section{REFRENCES}

1. Abrams P, Cardozo L, Fall M, Griffiths D, Rosier P, Ulmsten U, et al. The standardisation of terminology in lower urinary tract function: report from the Standardisation Sub-committee of the International Continence Society. Neurourol Urodyn 2002;21:167-78.

2. Verghese TS, Middleton LJ, Daniels JP, Deeks JJ, Latthe PM. The impact of urodynamics on treatment and outcomes in women with an overactive bladder: a longitudinal prospective follow-up study. Int Urogynecol J 2018;29(4);513-9. doi: 10.1007/s00192-017-3414-4.

3. Gulur DM, Drake MJ. Management of overactive bladder. Nat Rev Urol 2010;7(10):572-82.

4. Nowara A, Witek A. Naglący problem menopauzy. Prz Menopauz 2007;6:352-6. 
5. Gormley EA, Lightner DJ, Burgio KL, Chai TC, Clemens JQ, Culkin DJ, et al. Diagnosis and treatment of overactive bladder (non-neurogenic) in adults: AUA/SUFU guideline. J Urol 2012;188(Suppl. 6):2455-63.

6. Arnold J, McLeod N, Thani-Gasalam R, Rashid P. Overactive bladder syndrome - management and treatment options. Aust Fam Physician 2012;41(11):878-83.

7. Oskay UY, Beji NK, Yalcin O. A study on urogenital complaints of postmenopausal women aged 50 and over. Acta Obstet Gynecol Scand 2005;84(1):72-8

8. Stewart WF, Van Rooyen JB, Cundiff GW, Abrams P, Herzog AR, Corey R, et al. Prevalence and burden of overactive bladder in the United States. World J Urol 2003;20(6):327-36.

9. Milsom I, Abrams P, Cardozo L, Roberts RG, Thüroff J, Wein AJ. How widespread are the symptoms of an overactive bladder and how are they managed? A population-based prevalence study. BJU Int 2001;87(9):760-6.

10. Sako T, Inoue M, Watanabe T, Ishii A, Yokoyama T, Kumon H. Impact of overactive bladder and lower urinary tract symptoms on sexual health in Japanese women. Int Urogynecol J 2011;22(2):165-9.

11. Shin JH, Kim A, Choo MS. Additional low-dose antimuscarinics can improve overactive bladder symptoms in patients with suboptimal response to beta 3 agonist monotherapy. Investig Clin Urol 2017;58(4):261-6.

12. Jankiewicz K, Kulik-Rechberger B, Nowakowski Ł, Rechberger T. Czynnik wzrostu nerwów (NGF) jako biomarker w diagnostyce i terapii pęcherza nadreaktywnego (OAB). Ginekol Pol 2012;83(7):532-6.

13. Rechberger T, Kulik-Rechberger B, Miotła P, Wróbel A. Nowa era w farmakologicznym leczeniu pęcherza nadreaktywnego (OAB): mirabegron - selektywny agonista receptora $\beta 3$. Ginekol Pol 2014;85(3):214-9.

14. Bender S, Borowski J, Borkowski T, Torz C, Radziszewski P. Nietrzymanie moczu. Med Dypl 2011;20(6):73-80.

15. Jabbari B. History of botulinum toxin treatment in movement disorders. Tremor Other Hyperkinet Mov (N Y) 2016;6:394.

16. Drożdżyńska M, Sobieraj-Garbiak I, Chlasta A, Jastrzębska M. Toksyna botulinowa i i jej zastosowanie w medycynie. Diagn Lab 2015;51(2):139-46.

17. Pellett S, Bradshaw M, Tepp WH, Pier CL, Whitemarsh RCM, Chen C, et al. The light chain defines the duration of action of botulinum toxin serotype A subtypes. MBio 2018;9(2). pii: e00089-18. doi: 10.1128/mBio.00089-18.

18. Zeino M, Becker T, Koen M, Berger C, Riccabona M. Long-term follow-up after botulinum toxin A (BTX-A) injection into the detrusor for treatment of neurogenic detrusor hyperactivity in children. Cent European J Urol 2012;65(3):156-61.

19. Jasiński M, Drewa T, Tyloch J, Wolski Z. Is botulinum toxin type a intraprostatic injections really effective in patients with urinary retention? Acta Pol Pharm 2011;68(5):765-8.
20. Rechberger T, Wróbel A, Kokot M, Bartuzi A. Toksyna botulinowa - nowa opcja terapeutyczna w leczeniu zaburzeń czynnościowych pęcherza moczowego. Fam Med Primary Care Rev 2008;10(3):1040-4.

21. Gardner AP, Barbieri JT. Light Chain Diversity among Botulinum Neurotoxins. Toxins (Basel) 2018;10(7). pii: E268. doi: 10.3390/toxins10070268.

22. Sławek J, Rudzińska M, editor. Toksyna botulinowa w praktyce neurologicznej. Gdańsk: Via Medica; 2015.

23. Dykstra DD, Sidi AA, Scott AB, Pagel JM, Goldish GD. Effects of botulinum A toxin on detrusor-sphincter dyssynergia in spinal cord injury patients. J Urol 1988;139(5):919-22.

24. Rechberger T, Miotła P, Skorupski P, Wróbel A, Tomaszewski J. Jakość życia pacjentek z pęcherzem nadreakty wnym po zastosowaniu toksyny botulinowej - doniesienie wstępne. Ginekol Pol 2010;81:24-30.

25. Eldred-Evans D, Dasgupta P. Use of botulinum toxin for voiding dysfunction. Transl Androl Urol 2017;6(2):234-51.

26. Denys P, Dmochowski R, Aliotta P, Castro-Diaz D, Blok B, Ethans K, et al. Positive outcomes with first onabotulinumtoxinA treatment persist in the long term with repeat treatments in patients with neurogenic detrusor overactivity. BJU Int 2017;119(6):926-32.

27. Eldred-Evans D, Sahai A. Medium- to long-term outcomes of botulinum toxin A for idiopathic overactive bladder. Ther Adv Urol 2017;9(1):3-10.

28. Mohee A, Khan A, Harris N, Eardley I. Long-term outcome of the use of intravesical botulinum toxin for the treatment of overactive bladder (OAB). BJU Int 2013;111(1):106-13.

29. Drake MJ, Nitti VW, Ginsberg DA, Brucker BM, Hepp Z, McCool R, et al. Comparative assessment of the efficacy of onabotulinumtoxin $A$ and oral therapies (anticholinergics and mirabegron) for overactive bladder: a systematic review and network meta-analysis. BJU Int 2017;120(5):611-22.

30. Sherif H, Khalil M, Omar R. Management of refractory idiopathic overactive bladder: intradetrusor injection of botulinumtoxin type A versus posterior tibial nerve stimulation. Can J Urol 2017;24(3):8838-46.

31. Ferreira RS, D'Ancona CAL, Oelke M, Carneiro MR. Intradetrusor onabotulinumtoxin A injections are significantly more efficacious than oral oxybutynin for treatment of neurogenic detrusor overactivity: results of a randomized, controlled, 24-week trial. Einstein (Sao Paulo) 2018;16(3):eA04207.

32. Carneiro Neto JA, Santos SB, Orge GO, Tanajura D, Passos L, Oliveira CJ, et al. Onabotulinumtoxin type A improves lower urinary tract symptoms and quality of life in patients with human T cell lymphotropic virus type 1 associated overactive bladder. Braz J Infect Dis 2018;22(2):79-84.

33. Mühlstädt S, Mischner S, Kranz J, Anheuser P, Mohammed N, Steffens JA, et al. Quo vadis botulinum toxin: Normative constraints and quality of life for patients with idiopathic OAB?. Front Surg 2018; 5:61. 